Sterne, M. (1958). J. gen. Microbiol. 18, 747-750

\title{
The Growth of Brucella abortus Strain 19 in Aerated Dialysed media
}

\author{
By M. STERNE \\ Wellcome Research Laboratories, Beckenham, Kent
}

SUMMARY: An apparatus for growing Brucella abortus in a dialysed medium in an aerated cellophan tube is described from which $500 \mathrm{ml}$. of culture of strain 19 having a density of 7 to $10 \times 10^{11}$ organisms/ml., equivalent to 50-70 g. dry weight of organisms/l. could be harvested every 3 days.

The production of vaccine from Brucella abortus strain 19 grown on the surface of solid media is extremely costly because of the high rate of contamination, and of the low yield. Little interest has been shown in deep culture methods for the routine production of Brucella vaccine in spite of promising experimental results by a number of workers (Gerhardt \& Gee, 1946; Glassman \& Elberg, 1946; Saunders \& Huddleson, 1950). Sterne \& Wentzel (quoted by van Drimmelen, 1952) obtained c. $150 \times 10^{9}$ viable Brucella abortus/ml. in shake flasks in volumes of 3-4 l. This method was further developed by van Drimmelen (1956) and is used in South Africa for routine vaccine preparation. Dr G. P. Gladstone in 1947 (personal communication) obtained large harvests of Salmonella typhi in media aerated in cellophan tubes, and later (Gladstone, 1948) used a similar technique for preparing anthrax immunizing antigen. Gorelik, Mead \& Kelly (1951) showed that the growth of Brucella suis in shake flasks could be increased by enclosing the medium in cellophan sacs. Anderson $(1953,1954,1955)$ at the South African Institute for Medical Research has obtained yields of $S$. typhi up to $1.2 \times 10^{11}$ organisms $/ \mathrm{ml}$. in aerated cellophan tubes, and Dr J. H. Mason of the same Institute suggested that the method should be tried for growing $B$. abortus. The apparatus described below is virtually identical with that used by Fredette \& Vinet (1952) for growing Clostridium tetani. It is simple to operate and has yielded up to $1 \cdot 8 \times 10^{12}$ viable organisms $/ \mathrm{ml}$. with $B$. abortus strain 19 .

\section{METHODS}

Apparatus. Figure 1 shows a drawing of the apparatus used. The culture vessel $K$ is $780 \mathrm{~mm}$. long and $80 \mathrm{~mm}$. diam. The constricted ends $H$ and $H_{1}$ are $48 \mathrm{~mm}$. diam. and $40 \mathrm{~mm}$. long. Tubes $I_{1}$ and $I$ are for inflow and outflow of medium respectively. $L$ is a cellophan tube (Visking's regenerated cellulose tubing, diam. $1 \frac{7}{8}$ in.). This tubing is well soaked in water, threaded through $K$, and the ends reflected over $H$ and $H_{1}$ where they are held in position by rubber pads (25 mm. thick) $F$ and $F_{1}$ clamped between metal disks $E$ and $E_{1}$ by means of three equally spaced $\frac{1}{4}$ in. threaded metal rods $B$ furnished with wing nuts; only two of these rods are shown in the figure. $M$ is a sparger 
formed of a $40 \mathrm{~mm}$. no. 3 sintered disk which is connected to an air supply through a humidifier and a filter (not shown). $N$ is a pyrex $Y$-piece, one branch of which is connected to a reservoir containing physiological saline, while the other branch is used for sampling and harvesting the culture and for steaming the apparatus (see below). $A$ is a $500 \mathrm{ml}$. boiling flask with a tube $C, 25 \mathrm{~mm}$. diam., fused into the bottom. This is connected to a $25 \mathrm{~mm}$. diam. tube $D$ which pierces $F$. $G$ is a stainless steel spiral to prevent deformation of the cellophan tube $\boldsymbol{L}$ during aeration.

The apparatus is assembled as shown and furnished with appropriate rubber connexions for attachment to the reservoirs for medium and saline, the air-line, and a reservoir for spent medium. About $50 \mathrm{ml}$. distilled water are introduced into the cellophan tube $L$, the wing nuts tightened sufficiently to make a good seal between the ends $H$, the cellophan tube $L$ and the rubber pad $F$, and the whole apparatus then autoclaved. After sterilization, the apparatus can be left for long periods, assembled and ready for use, without risk of contamination.

Medium. The culture medium used was virtually the same as that suggested by van Drimmelen (1952): $3 \%(w / v)$ 'peptone' (the peptone was a papain digest of horse muscle containing $17 \mathrm{~g}$. total-N/100 g.); $3 \%(w / v)$ glucose; $1 \%(w / v)$ Marmite; $0 \cdot 15 \%(w / v)$ anhydrous $\mathrm{Na}_{2} \mathrm{HPO}_{4}$. The $\mathrm{pH}$ was adjusted to 6.4 and the medium sterilized by filtration through Seitz pads.

Operation of the apparatus. The cellophan

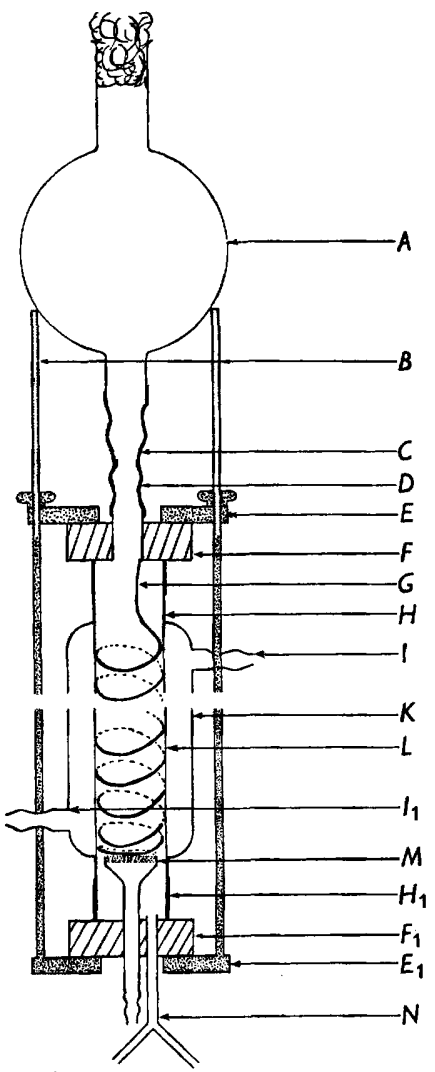

Fig. 1. Apparatus for deep culture of Brucella abortus. tube $L$ is filled through $N$ with $c .1000 \mathrm{ml}$. physiological saline from a reservoir and the surrounding annular space filled with c. $1500 \mathrm{ml}$. medium from another reservoir through $I_{1}$. After diffusion has proceeded for about $4 \mathrm{hr}$. the diffusate in $L$ is inoculated with the washings of an agar slope culture of Brucella abortus strain 19 together with antifoam (Dow-Corning silicone antifoam $A$ in technical light oil) and air is passed through at the rate of $250 \mathrm{ml} . / \mathrm{min}$. The whole apparatus is incubated in a hot room at $37^{\circ} \mathrm{C}$. After $24 \mathrm{hr}$. growth a drip of $400 \mathrm{ml}$. of medium/ $24 \mathrm{hr}$. is started. The culture is harvested after 3-4 days, the cellophan tube then refilled with saline and fresh medium run into the annular space. Growth is more rapid in the second and subsequent cycles because of the large residue of actively growing organisms left from the previous run.

In order to avoid the development of mutants, the apparatus is steamed after four to six cycles by attaching a wash bottle of sterile distilled water to 
the harvesting nozzle $N$ and boiling the water over a gas ring. In practice, there has been little tendency for rough variants to appear so long as there is no interruption to the air supply.

\section{RESULTS}

The results of eight successive batches are given in Table 1. Clearly, the number of organisms $/ \mathrm{ml}$. varied inversely as the volume harvested. This was due to concentration by dialysis since there was virtually no increase in the

Table 1. Details of eight successive batches (28 harvests) of Brucella abortus strain 19 grown in aerated dialysed medium

\begin{tabular}{|c|c|c|c|c|c|c|c|c|}
\hline Batch & Cycle & $\begin{array}{l}\text { Volume } \\
\text { harvested } \\
\text { (ml.) }\end{array}$ & $\begin{array}{c}\text { Opacity } \\
\text { by } \\
\text { Brown's } \\
\text { tubes }\end{array}$ & $\begin{array}{c}\text { Yield of } \\
\text { organisms } \\
\text { (equiva- } \\
\text { lent g. } \\
\text { dry } \\
\text { weight/l.) }\end{array}$ & $\begin{array}{c}\text { Total } \\
\text { yield of } \\
\text { organisms } \\
\text { in harvest } \\
\text { (equiva- } \\
\text { lent g. } \\
\text { dry } \\
\text { weight) }\end{array}$ & $\begin{array}{c}\text { No. of viable } \\
\text { organisms/ml. } \\
\text { harvest } \\
\left(\times 10^{9}\right)\end{array}$ & $\begin{array}{c}\text { Total no. } \\
\text { viable } \\
\text { organisms } \\
\text { in harvest } \\
\left(\times \mathbf{1 0}^{12}\right)\end{array}$ & $\begin{array}{l}\text { No. viable } \\
\text { organisms/g. } \\
\text { dry weight } \\
\text { organisms } \\
\left(\times 10^{12}\right)\end{array}$ \\
\hline 4 & $\begin{array}{l}\mathbf{1} \\
\mathbf{2} \\
\mathbf{3}\end{array}$ & $\begin{array}{l}850 \\
750 \\
400\end{array}$ & $\begin{array}{l}350 \\
450 \\
800\end{array}$ & $\begin{array}{l}28 \cdot 9 \\
45 \cdot 8 \\
77 \cdot 2\end{array}$ & $\begin{array}{l}24 \cdot 6 \\
34 \cdot 4 \\
30 \cdot 9\end{array}$ & $\frac{496}{1015 \pm 32}$ & $\frac{422}{406 \pm 13}$ & $\frac{17 \cdot 2}{13 \cdot 1 \pm 0 \cdot 4}$ \\
\hline 5 & $\begin{array}{l}\mathbf{1} \\
\mathbf{2} \\
\mathbf{3} \\
\mathbf{4} \\
\mathbf{5}\end{array}$ & $\begin{array}{l}510 \\
350 \\
425 \\
600 \\
600\end{array}$ & $\begin{array}{l}350 \\
650 \\
500 \\
400 \\
500\end{array}$ & $\begin{array}{l}36 \cdot 5 \\
67 \cdot 9 \\
54 \cdot 6 \\
34 \cdot 7 \\
48 \cdot 2\end{array}$ & $\begin{array}{l}18 \cdot 6 \\
23 \cdot 8 \\
23 \cdot 2 \\
20 \cdot 8 \\
28 \cdot 9\end{array}$ & $\begin{array}{r}448 \\
960 \pm 64 \\
640 \pm 48 \\
547 \pm 48 \\
1080 \pm 90\end{array}$ & $\begin{array}{l}228 \\
336 \pm 23 \\
272 \pm 21 \\
328 \pm 29 \\
648 \pm 54\end{array}$ & $\begin{array}{l}12 \cdot 8 \\
14 \cdot 1 \pm 1 \cdot 0 \\
11 \cdot 6 \pm 0 \cdot 9 \\
15 \cdot 8 \pm 1 \cdot 4 \\
22 \cdot 4 \pm 1 \cdot 9\end{array}$ \\
\hline 6 & $\begin{array}{l}1 \\
2 \\
3 \\
4 \\
5 \\
6\end{array}$ & $\begin{array}{l}\mathbf{3 7 5} \\
\mathbf{5 0 0} \\
\mathbf{5 0 0} \\
\mathbf{3 7 0} \\
\mathbf{5 8 0} \\
\mathbf{3 5 0}\end{array}$ & $\begin{array}{l}600 \\
500 \\
640 \\
700 \\
350 \\
750\end{array}$ & $\begin{array}{l}72 \\
43 \cdot 9 \\
- \\
76 \cdot 3 \\
29 \cdot 5 \\
75 \cdot 9\end{array}$ & $\begin{array}{l}27 \\
22 \\
\overline{28 \cdot 2} \\
17 \cdot 1 \\
26 \cdot 6\end{array}$ & $\begin{array}{r}1156 \pm 56 \\
509 \pm 18 \\
824 \pm 58 \\
1021 \pm 54 \\
562 \pm 32 \\
1616 \pm 93\end{array}$ & $\begin{array}{l}434 \pm 21 \\
255 \pm 9 \\
412 \pm 29 \\
378 \pm 20 \\
325 \pm 19 \\
565 \pm 33\end{array}$ & $\begin{array}{r}16 \pm 0.8 \\
11 \cdot 6 \pm 0.4 \\
- \\
13 \cdot 4 \pm 0.7 \\
19 \cdot 0 \pm 1 \cdot 1 \\
21 \cdot 2 \pm 1.2\end{array}$ \\
\hline 7 & 1 & 500 & 520 & $58 \cdot 3$ & $29 \cdot 2$ & $858 \pm 48$ & $429 \pm 24$ & $14.7 \pm 0.8$ \\
\hline 8 & $\begin{array}{l}1 \\
2\end{array}$ & $\begin{array}{l}550 \\
600\end{array}$ & $\begin{array}{l}320 \\
300\end{array}$ & $\begin{array}{l}34 \cdot 7 \\
38 \cdot 2\end{array}$ & $\begin{array}{l}19 \cdot 1 \\
22 \cdot 9\end{array}$ & $\begin{array}{l}536 \pm 39 \\
389 \pm 32\end{array}$ & $\begin{array}{l}295 \pm 22 \\
233 \pm 19\end{array}$ & $\begin{array}{l}15 \cdot 4 \pm 1 \cdot 1 \\
10 \cdot 2 \pm 0 \cdot 9\end{array}$ \\
\hline 9 & $\begin{array}{l}1 \\
2 \\
3 \\
4\end{array}$ & $\begin{array}{l}460 \\
460 \\
500 \\
420\end{array}$ & $\begin{array}{l}450 \\
500 \\
480 \\
500\end{array}$ & $\begin{array}{l}48 \cdot 9 \\
49 \cdot 4 \\
46 \cdot 2 \\
50 \cdot 1\end{array}$ & $\begin{array}{l}22 \cdot 5 \\
22 \cdot 8 \\
23 \cdot 1 \\
21\end{array}$ & $\begin{array}{l}691 \pm 43 \\
698 \pm 45 \\
909 \pm 38 \\
811 \pm 43\end{array}$ & $\begin{array}{l}318 \pm 20 \\
321 \pm 22 \\
455 \pm 19 \\
341 \pm 18\end{array}$ & $\begin{array}{l}14.1 \pm 0.9 \\
14.1 \pm 0.9 \\
19 \cdot 7 \pm 0.8 \\
16.2 \pm 0.9\end{array}$ \\
\hline 10 & $\begin{array}{l}\mathbf{1} \\
\mathbf{2} \\
\mathbf{3} \\
\mathbf{4}\end{array}$ & $\begin{array}{l}530 \\
430 \\
455 \\
430\end{array}$ & $\begin{array}{l}420 \\
630 \\
480 \\
500\end{array}$ & $\begin{array}{l}40 \cdot 4 \\
57 \cdot 7 \\
45 \cdot 4 \\
54\end{array}$ & $\begin{array}{l}21 \cdot 4 \\
24 \cdot 8 \\
20 \cdot 7 \\
23 \cdot 2\end{array}$ & $\begin{array}{c}749 \pm 58 \\
1280 \pm 141 \\
883 \pm 64 \\
672 \pm 58\end{array}$ & $\begin{array}{l}397 \pm 32 \\
550 \pm 52 \\
393 \pm 29 \\
289 \pm 25\end{array}$ & $\begin{array}{l}18 \cdot 5 \pm 1 \cdot 5 \\
22 \cdot 2 \pm 2 \cdot 1 \\
18 \cdot 9 \pm 1 \cdot 4 \\
12 \cdot 5 \pm 1 \cdot 1\end{array}$ \\
\hline 11 & $\begin{array}{l}\mathbf{1} \\
\mathbf{2} \\
\mathbf{3}\end{array}$ & $\begin{array}{l}600 \\
450 \\
240\end{array}$ & $\begin{array}{r}250 \\
540 \\
1200\end{array}$ & $\frac{64}{117}$ & $\begin{array}{l}-\overline{28 \cdot 8} \\
28 \cdot 1\end{array}$ & $\begin{array}{c}- \\
970 \pm 74 \\
1797 \pm 168\end{array}$ & $\begin{array}{c}- \\
437 \pm 34 \\
431 \pm 40\end{array}$ & $\begin{array}{c}- \\
15 \cdot 1 \pm 1 \cdot 2 \\
15 \cdot 3 \pm 1 \cdot 4\end{array}$ \\
\hline
\end{tabular}

total number of viable organisms between 72 and $96 \mathrm{hr}$. An average expectation was a harvest of $500 \mathrm{ml}$. containing 7 to $10 \times 10^{11}$ viable organisms $/ \mathrm{ml}$. equivalent to 50-70 g. dry wt. organisms/l. The average total harvest was $c .400 \times 10^{12}$ viable organisms/batch. The fluctuation in the proportion of viable 
organisms (column 9) was more apparent than real and reflected mainly variations in the efficiency of the medium on which the viable counts were made.

A harvest of $400 \times 10^{12}$ organisms makes 6000-7000 doses of vaccine, and an average of six cycles/month can be maintained comfortably, so that 400,000 to 500,000 doses/year can be produced by one such apparatus which, with all its accessories, occupies only $4.5 \mathrm{sq} . \mathrm{ft}$. of incubator floor space. The labour required is a fraction of that needed for producing similar amounts of vaccine by conventional methods.

I am indebted to Dr J. H. Mason of the South African Institute for Medical Research for stimulating interest in this method, and to Dr Fredette for suggesting the very effective method of clamping the cellophan. I should also like to acknowledge the valuable help given by Mr I. Hutchinson and Mr D. Wetherby of the Wellcome Research Laboratories.

\section{REFERENCES}

Anderson, C. G. (1953). Rep. S. Afr. Inst. med. Res. p. 32.

Anderson, C. G. (1954). Rep. S. Afr. Inst. med. Res. p. 36.

Anderson, C. G. (1955). Rep. S. Afr. Inst. med. Res. p. 37.

Drimmelen, G. C. van (1952). Brucella abortus Strain 19 vaccine more readily available. J. S. Afr. vet. med. Ass. 23, 149

Drimmelen, G. C. van (1956). Strain 19 Brucella vaccine-1. Production of vaccine by the shake flask technique. Onderstepoort J. vet. Res. 27, 205.

Fredette, V. \& Vinet, G. (1952). Production en sac de cellophane de toxines tétanique renferment au moins 600,000 doses mortelles (cobaye) par millilitre. Canad. J. med. Sci. 30, 155.

Gerhardt, P. \& Gee, L. L. (1946). Brucella suis in aerated broth culture. 1. Preliminary studies on growth assays, inoculum, and growth characteristics in an improved medium. J. Bact. 52, 261.

Gradstone, G. P. (1948). Immunity to anthrax. Production of the cell-free protective antigen in cellophane sacs. Brit. J. exp. Path. 29, 379.

Glassman, H. N. \& Elberg, S. (1946). The growth of Brucella in aerated liquid cultures. J. Bact. 52, 423 .

Gorelik, A. N., Mead, D. D. \& Kelly, E. H. (1951). The growth of bacteria in a charcoal-cellophane system. J. Bact. 61, 507.

Saunders, E. \& Huddleson, I. F. (1950). The influence of atmospheric gases on the multiplication of Brucella. Amer. J. vet. Res. 11, 70.

(Received 1 January 1958) 